\title{
Risk assessment due to intake of trace metals through the ingestion of groundwater around proposed uranium mining areas of Nalgonda district, Telangana, India
}

\author{
T. Raghavendra ${ }^{1}$ S. U. B. Ramakrishna ${ }^{1}$ - D. Srinivasulu ${ }^{1} \cdot$ T. Vijayalakshmi $^{1}$ - V. Himabindu ${ }^{1}$. J. Arunachalam ${ }^{2}$
}

Received: 31 January 2017 / Accepted: 30 October 2019 / Published online: 15 November 2019

(c) The Author(s) 2019

\begin{abstract}
In the context of proposed uranium mining area, it is very important to evaluate the presence of certain trace metals in groundwater around a proposed uranium mining area at Peddagattu and Seripally areas of Nalgonda district, Telangana (India). The concentrations of certain metals ( $\mathrm{Cu}, \mathrm{Zn}, \mathrm{Ni}, \mathrm{Pb}, \mathrm{Fe}, \mathrm{Mn}, \mathrm{Cd}, \mathrm{Co}, \mathrm{Sr}, \mathrm{Ba}, \mathrm{Cr}, \mathrm{Cs}$ and $\mathrm{As}$ ) were measured in 37 groundwater locations and 10 surface water locations for seven times during 2 years around proposed uranium mining areas. The risk of the chemical toxicant [may be characterized using a hazard quotient (HQ)] is calculated by the results obtained during the study. The HQs of both groundwater (37) and surface water (10) all the considered trace metals were well below the threshold value of 1 as suggested by USEPA.
\end{abstract}

Keywords Risk assessment · Trace elements · Groundwater · Surface water · Ingestion · Proposed uranium mine

\section{Introduction}

Trace metal contamination in the aquatic ecosystem has paying global attention to its abundance, persistence and environmental toxicity (Islam et al. 2015a; Ahmed et al. 2015a, b). Natural and anthropogenic activities are responsible for the contamination of trace metals in the environment (Wilson and Pyatt 2007; Khan et al. 2008). However, anthropogenic activities are the major contributor, which generating the trace metals in sediment and water that pollute the aquatic ecosystem.

The aquatic ecosystem is frequently the ultimate recipient of trace metal pollution from various sources-industrial wastewater, urban surface water runoff, accidental discharges into the aquatic environment through exploration and exploitation of natural resources, geological formation and weathering, agricultural practices, etc. (Masoud et al.

V. Himabindu

trv.jntu@gmail.com

1 Center for Environment, Institute of Science and Technology, Jawaharlal Nehru Technological University Hyderabad, Room No 515, 4th floor, Kukatpally, Hyderabad, AP 500085, India

2 NCCCM Hyderabad, Bhabha Atomic Research Center, Mumbai, India
2005; Gupta et al. 2009). Sediments have been widely used as environmental indicators for the assessment of metal pollution in the natural water (Islam et al. 2015b). During transportation of trace metals in the environment, they may undergo frequent changes due to dissolution, precipitation and sorption phenomena (Abdel-Ghani and Elchaghaby 2007), which affect their performance and bioavailability (Nouri et al. 2011).

In case of uranium mining, radionuclides and other metals can find their way into the water resources approximately the facilities involved in mining, milling, ore separation and purification. Leaching of metals, nonmetals and radionuclides from surface impoundments of tailings generated during uranium mining and milling often leads to groundwater contamination. Some of these metals reported to produce severe diseases like cancer, kidney failure, liver damage and neurological and genetic malfunctions (Abbasi et al. 1998; Johnson 1998; Lasheen et al. 2008; Miller et al. 2004). Thus, monitoring of ground and surface water surrounding uranium mines has great significance from a human health perspective.

Drinking water can come from either groundwater sources (e.g., wells, tube wells) or surface water sources (rivers, lakes, streams, etc.). More than 50\% of the world's population depends on groundwater for drinking (Fry 2005). For many rural and small communities, groundwater is the 
only source of drinking water (Hani 1990). Since groundwater moves through rocks and subsurface soil, it has a lot of opportunity to dissolve substances as it moves. Water can pick up heavy metals and radioactive material in a uranium mining area as it flows through the rocks or soil, therefore contaminating that water source. Depending upon the geological formations, the quality of groundwater also varies from place to place. The concentration and distribution of heavy metals and radionuclides in groundwater vary from one area to another depending on the variables, i.e., geological locations, $\mathrm{pH}$, redox potential, radionuclide solubility and half-life, grade of uranium ore deposits, hydro-geometry of aquifers, etc.

Risk assessment modeling is subdivided into main four stages, i.e., hazard identification, exposure assessment, toxicity (dose-response) assessment and risk characterization. In order to assess exposure, it is necessary to calculate the average daily dose (ADD) of contaminant via the three identified pathways (soil, groundwater and food pathways). In dose-response assessment for non-carcinogens, reference doses (RfD) are calculated and that for carcinogens, slope factors (SF) are obtained by United States Environmental Protection Agency (USEPA) Integrated Risk Information System (IRIS) database. In risk characterization, the results of toxicity assessment calculate the risk or hazard resulting from potential exposure to chemicals via the pathways and routes of exposure determined appropriate for the source area. In the present study, risk assessment of metals in drinking water through the ingestion is taken into consideration.

\section{Materials and method}

\section{About study area}

The study areas, namely Peddagattu and Seripally, are contiguous and bound by latitudes $16^{\circ} 35^{\prime}-16^{\circ} 50^{\prime}$ and longitudes $78^{\circ} 46^{\prime}-79^{\circ} 17^{\prime}$. Each study area covers nearly $30 \mathrm{~km}^{2}$ located at a distance of about $135 \mathrm{~km}$ east-southeast (ESE) of Hyderabad and forms a part of Nalgonda district, Telangana, India (Fig. 1). It covers the proposed Nambapur and

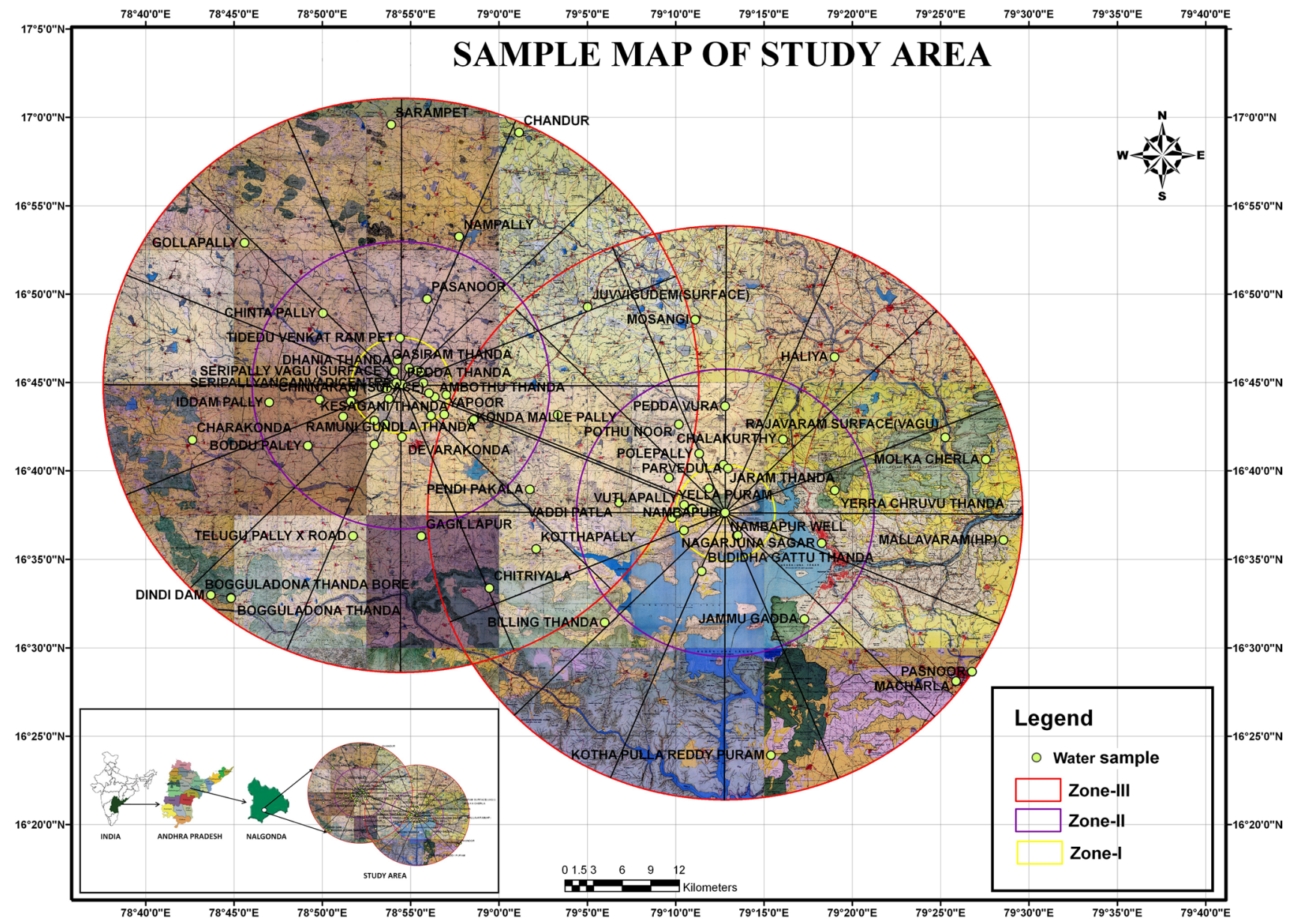

Fig. 1 Map showing the study locations selected around the proposed uranium mining area 
Peddagattu uranium mining areas and Seripally tailings pond area.

The southeastern side of the study area is surrounded by the Nagarjuna Sagar reservoir, and the southern side of the area is bounded by Peddavagu River. The northern side is bounded by Gudipalli Vagu River. This area experiences arid to semiarid climate. The study area goes through hot climate during the summer (April-June) with a temperature ranging from 30 to $46.5^{\circ} \mathrm{C}$, and in winter (November-January), it varies between 17 and $38{ }^{\circ} \mathrm{C}$. The annual rainfall during 2012 is $674 \mathrm{~mm}$, falling mostly during the southwest monsoon (June-September).

The topography of the area comprises an undulating terrain dotted with few hills and has maximum of $348 \mathrm{~m}$ in the northwestern side to a minimum of $169 \mathrm{~m}$ in northeastern side. Agriculture is the main land use in this area. Paddy, pulses and sweet lemon are widely grown (CGWB Annual Report 2012-13).

Most part of the investigated area has exposures of granitic rocks belonging to late Archaen. Granites are generally medium to coarse grained. The Srisailam Formation is exposed in the southeastern part of the study area. The sediments of Srisailam Formation are mainly sandstones and include pebbly gritty quartzite shale with dolomitic limestone, intercalated sequence of shale-quartzite and massive quartzite.

\section{Sampling methodology for water samples}

In each study area, water samples have been collected for seven times (once in a quarter) from May 2010 to December 2011, based on the grid sampling system. For grid sampling, the study areas were divided into 3 concentric zones of 0-5 km (core zone), 5-15 km (buffer zone I) and 15-30 km (buffer zone II). Each zone has been divided radially into 16 sectors as shown in Fig. 1. In the core zone $(0-5 \mathrm{~km})$, more intensive sampling has been done representing one sample per each sector; in the buffer zone I (5-10 km radius) for every four sectors, one sample has been collected. In the buffer zone II (15-30 km), one sample has been collected for every six sectors. Thus, in all total 390 water samples from 47 sampling locations have been collected for this study.

Water samples were collected in clean polyethylene bottles. The sampling bottles were soaked in diluted nitric acid solution for $24 \mathrm{~h}$ and washed with distilled water and again with the respective sample. Samples were collected after at least 5-10 min of pumping to evacuate rust in hand pumps. For the estimation of trace elements 2-1, water sample was collected and filtered with Whatman filter paper and preserved by adjusting the $\mathrm{pH}<2$ with concentrated ultrapure nitric acid (EPA-1 2015). Proper quality assurance procedures and safeguards were carried out to ensure reliability, and samples were cautiously handled to escape contamination. Glassware was properly washed, and analytical (AR) grade reagents were used. Double distilled water was used during the study. Reagent blank determinations were used to precise the instrument analyses.

For authentication of the analytical procedure, a recovery study was carried out by adopting the reference material and spiking of several already analyzed samples with mixed amounts of standard solutions of the trace metals to verify the results obtained. It has been found that the recovery values are in the range of $89.3-102.3 \%$. The analytical values obtained are within the range of certified values. Standards were run intermediately in between every 15 samples analyzed. This outcome indicates good quality of results that are obtained in the current study.

\section{Results and discussion}

\section{Baseline survey of trace metals in water samples}

Total 390 water samples collected during different seasons from 47 locations of Peddagattu and Seripally regions as shown in Fig. 1 have been analyzed for all the trace metals. Statistical analysis of the results was carried out, and the minimum, maximum values and geo mean (Helsel 2005) with standard deviation of trace metals in Peddagattu and Seripally regions are given in Table 1 . In order to obtain detailed statistical information, the principal component analysis of trace metals was calculated and relations between them were studied.

\section{Principal component analysis}

Principal component analysis (PCA) (Fig. 2) was a multivariate statistical technique used for data reduction and for interpreting patterns within large sets of data. The principal component analysis has identified three independent factors which were extracted and are presented in Fig. 2 and showed 93.2\% of the total variance. The first principal component was responsible for $50.3 \%$ of the total variance and was best represented by mainly participated by $\mathrm{Fe}, \mathrm{Ni}, \mathrm{Zn}, \mathrm{Sr}$. Principal component 2 explained $24.5 \%$ of the total variance and mainly participated by $\mathrm{Cr}, \mathrm{Cu}, \mathrm{As}, \mathrm{Co}$, and an additional $18.4 \%$ of the total variance was explained in principal component 3 mainly participated by $\mathrm{Pb}, \mathrm{Ba}, \mathrm{Cs}, \mathrm{Cd}$, and $\mathrm{Mn}$ which gave the most contribution. According to principal component analysis, the elements affecting the water quality are mainly by $\mathrm{Fe}, \mathrm{Ni}, \mathrm{Sr}$ and $\mathrm{Zn}$.

The trace element analysis was done by using AAS and ICP-OES. Except $\mathrm{Fe}, \mathrm{Ni}$ and $\mathrm{Cd}$, all other trace elements are falling well under the permissible limit (IS 10500 2012) in both Seripally and Peddagattu regions. Higher levels of trace metals were attributed to the corrosion in casing pipes of most 
Table 1 Results of trace elements in drinking water samples (Peddagattu and Seripally regions)

\begin{tabular}{llll}
\hline $\begin{array}{l}\text { Element concentration } \\
(\mathrm{ppm})\end{array}$ & Range min-max & Geo mean \pm SD & $\begin{array}{l}\text { Permissible limit (ppm) } \\
\text { (BIS 10500-2012 stand- } \\
\text { ards) }\end{array}$ \\
\hline $\mathrm{Cu}$ & $0.005-1.328$ & $0.018 \pm 0.043$ & 2 \\
$\mathrm{Zn}$ & $0.035-4.655$ & $0.100 \pm 0.052$ & 5 \\
$\mathrm{Ni}$ & $0.005-7.921$ & $0.149 \pm 0.069$ & 3.0 (maximum) \\
$\mathrm{Pb}$ & $0.018-0.403$ & $0.031 \pm 0.060$ & 0.05 \\
$\mathrm{Fe}$ & $0.042-15.722$ & $0.607 \pm 0.081$ & 0.3 \\
$\mathrm{Mn}$ & $0.006-1.134$ & $0.027 \pm 0.036$ & 0.4 \\
$\mathrm{Cd}$ & $0.005-0.323$ & $0.006 \pm 0.070$ & 0.003 \\
$\mathrm{Co}$ & $0.005-1.365$ & $0.018 \pm 0.059$ & - \\
$\mathrm{Sr}$ & $0.175-3.464$ & $0.445 \pm 0.053$ & 5 (USEPA) \\
$\mathrm{Ba}$ & $0.009-0.958$ & $0.081 \pm 0.026$ & 0.7 \\
$\mathrm{Cr}$ & $0.008-1.112$ & $0.014 \pm 0.012$ & 0.05 \\
$\mathrm{Cs}$ & $9.3 \times 10^{-6}-0.0253$ & $0.0001 \pm 0.002$ & - \\
$\mathrm{As}$ & $0.020-0.0741$ & $0.003 \pm 0.002$ & 0.05 \\
\hline
\end{tabular}

Fig. 2 Principal component analysis of trace metals in water

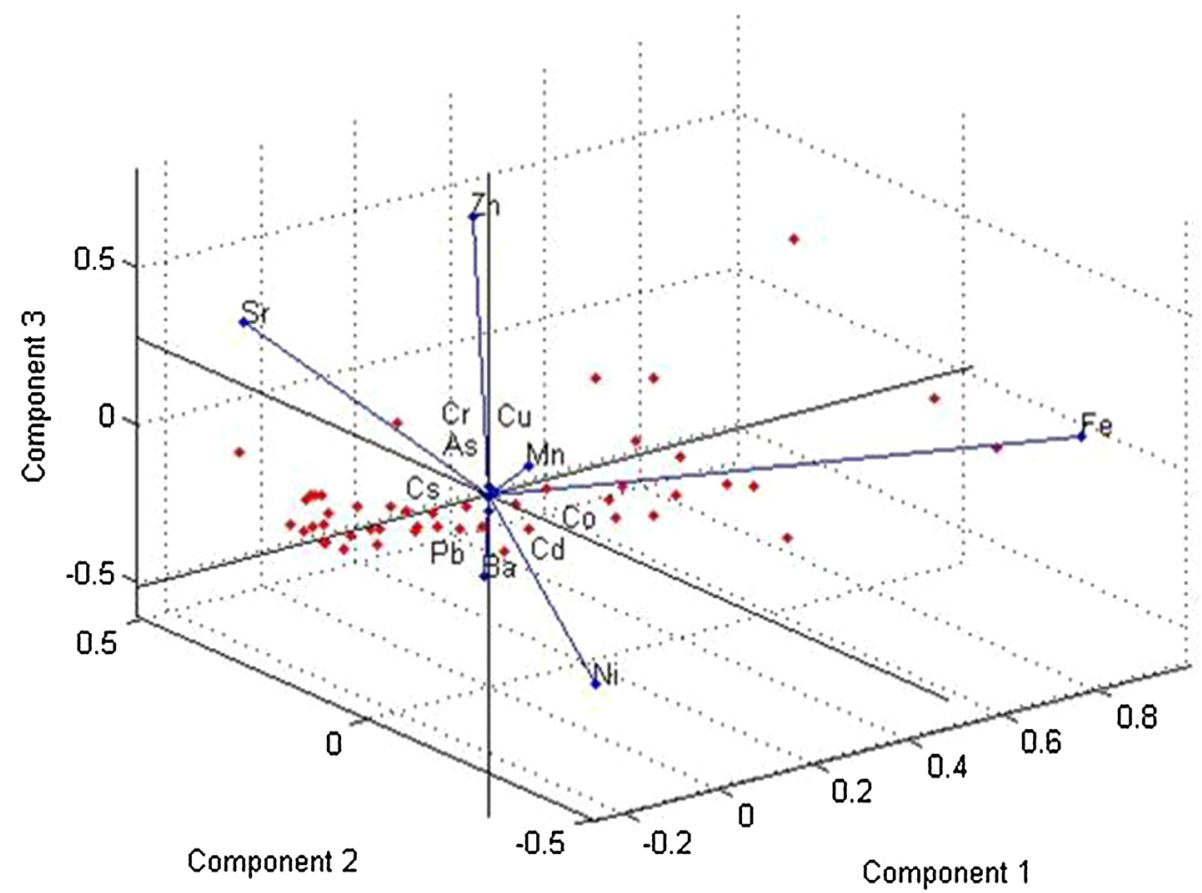

Component 1 of the hand pumps. The primary source of nickel in drinking water is leaching from metals in contact with drinking water such as pipes and fittings. However, it may also be present in some groundwaters because of dissolution from nickel orebearing rocks. The geogenic source appears to be responsible mainly for the nickel concentrations in groundwater of the study area (Tiwary and Mishra 1985).

\section{Risk assessment due to intake of heavy metals through the ingestion of water}

Risk of the chemical toxicant may be characterized using a hazard quotient (HQ). This is the ratio of the average daily dose (ADD; $\mathrm{mg} / \mathrm{kg}$ of body weight per day) of a chemical to a reference dose ( $\mathrm{RfD} ; \mathrm{mg} / \mathrm{kg}$ per day) defined as the 
maximum tolerable daily intake of a specific metal that does not result in any deleterious health effects:

$\mathrm{HQ}=\mathrm{ADD} / \mathrm{RfD}$

The average daily dose of $\mathrm{Cu}, \mathrm{Zn}, \mathrm{Ni}, \mathrm{Pb}, \mathrm{Fe}, \mathrm{Mn}, \mathrm{Cd}$, $\mathrm{Co}, \mathrm{Sr}, \mathrm{Ba}, \mathrm{Cr}, \mathrm{Cs}$ and As was computed to be $7.0 \times 10^{-4}$, $3.0 \times 10^{-3}, 6.0 \times 10^{-3}, 9.0 \times 10^{-4}, 2.4 \times 10^{-3}, 1.0 \times 10^{-3}$, $2.0 \times 10^{-4}, 1.0 \times 10^{-3}, 1.4 \times 10^{-2}, 4.0 \times 10^{-3}, 4.0 \times 10^{-4}$, $2.0 \times 10^{-5}$ and $2.0 \times 10^{-4}$, mg per $\mathrm{kg}$ body weight per day, respectively, for Peddagattu region and, in addition, $6.0 \times 10^{-4}, 4.0 \times 10^{-3}, 4.7 \times 10^{-3}, 1.0 \times 10^{-3}, 2.4 \times 10^{-3}$, $1.0 \times 10^{-3}, 2.0 \times 10^{-4}, 7.0 \times 10^{-4}, 1.5 \times 10^{-2}, 2.6 \times 10^{-3}$, $5.0 \times 10^{-4}, 1.0 \times 10^{-5}$ and $2.0 \times 10^{-4}$ for Seripally region (Table 2). However, to know the extent of potability of the water and the risk associated with the ingestion of heavy metals through water, hazard quotient was estimated for the heavy metals by the intake of the drinking water in both the study areas. The average daily dose was calculated by dividing the intake by the body weight of an average Indian man, i.e., $52 \mathrm{~kg}$ (Jain et al. 1995; Dang et al. 1996). The daily intake was estimated by taking the geometric mean concentration of the metals in water and the average water consumption of $1.48 \mathrm{~m}^{3}$ year ${ }^{-1}$ by an Indian adult (Dang et al. 1994). The RfD of all the heavy metals except $\mathrm{Pb}$ was considered from USEPA (1993). The RfD of Pb was taken from WHO (1993). Estimated exposure and hazard quotient due to intake of drinking water to local population are given in Table 2. The hazard quotients of the heavy metals suggest that the heavy metals in the drinking water pose no threat to the local people. The HQs of all the considered heavy metals were well below the threshold value of 1 as suggested by USEPA. If HQ $>1.00$, then the ADD of a particular metal exceeds the RfD, indicating that there is a potential risk associated with that metal. The HQ ranges from $2.4 \times 10^{-4}(\mathrm{Cr})$ to $3.8 \times 10^{-1}$ (As) for Peddagattu region while for Seripally region HQ ranged from $3.0 \times 10^{-4}(\mathrm{Cr})$ to $2.3 \times 10^{-1}(\mathrm{~Pb})$.

\section{Conclusions}

The analyses of trace metals in groundwater and surface water around various locations of the proposed uranium mining area was significant for establishing a baseline data prior to the start of mining. We find that except $\mathrm{Fe}, \mathrm{Ni}$ and $\mathrm{Cd}$, all other trace metal concentrations were generally less than permissible drinking water levels. The higher levels of $\mathrm{Fe}, \mathrm{Ni}$ and $\mathrm{Cd}$ were the geogenic source which appears to be responsible mainly for the nickel concentrations in groundwater of the study area. The hazard quotients (HQ) of all the considered trace metals for drinking water were well below 1 posing no threat to the local people for the both Peddagattu and Seripally proposed uranium mining areas. In addition, none of the single locations in any sampling period exceeded the maximum HQ value. The present study reveals that the groundwater and surface water were not polluted with trace metals despite geogenic source and other associated activities in the area.

Table 2 Concentration of trace metals in water samples of Peddagattu and Seripally proposed uranium mining area

\begin{tabular}{|c|c|c|c|c|c|c|c|c|}
\hline \multirow[t]{2}{*}{ S. no. } & \multirow[t]{2}{*}{ Trace metals } & \multirow[t]{2}{*}{ Rfd values $^{\mathrm{a}}$} & \multicolumn{3}{|c|}{ Peddagattu Region } & \multicolumn{3}{|c|}{ Seripally Region } \\
\hline & & & Intake $^{\mathrm{b}}$ & $\begin{array}{l}\text { Average daily } \\
\text { dose (ADD) }{ }^{\mathrm{c}}\end{array}$ & Hazard quotient (HQ) & Intake $^{b}$ & $\begin{array}{l}\text { Average daily } \\
\text { dose }(A D D)^{\mathfrak{c}}\end{array}$ & Hazard quotient (HQ) \\
\hline 1 & Copper $(\mathrm{Cu})$ & $4.0 \times 10^{-2}$ & $3.5 \times 10^{-2}$ & $7.0 \times 10^{-4}$ & $1.4 \times 10^{-2}$ & $3.2 \times 10^{-2}$ & $6.0 \times 10^{-4}$ & $1.1 \times 10^{-2}$ \\
\hline 2 & Zink (Zn) & $3.0 \times 10^{-1}$ & $1.56 \times 10^{-1}$ & $3.0 \times 10^{-3}$ & $8.0 \times 10^{-3}$ & $2.3 \times 10^{-1}$ & $4.0 \times 10^{-3}$ & $1.1 \times 10^{-2}$ \\
\hline 3 & Nikle (Ni) & $2.0 \times 10^{-2}$ & $2.9 \times 10^{-1}$ & $6.0 \times 10^{-3}$ & $2.3 \times 10^{-1}$ & $2.4 \times 10^{-1}$ & $4.7 \times 10^{-3}$ & $2.0 \times 10^{-1}$ \\
\hline 4 & Led $(\mathrm{Pb})$ & $3.5 \times 10^{-3}$ & $5.50 \times 10^{-2}$ & $9.0 \times 10^{-4}$ & $2.9 \times 10^{-1}$ & $4.6 \times 10^{-2}$ & $1.0 \times 10^{-3}$ & $2.3 \times 10^{-1}$ \\
\hline 5 & Iron $(\mathrm{Fe})$ & $7.0 \times 10^{-1}$ & 1.2400 & $2.4 \times 10^{-2}$ & $2.0 \times 10^{-2}$ & 1.2500 & $2.4 \times 10^{-2}$ & $2.0 \times 10^{-2}$ \\
\hline 6 & Manganese (Mn) & $2.4 \times 10^{-2}$ & $6.70 \times 10^{-2}$ & $1.0 \times 10^{-3}$ & $3.0 \times 10^{-2}$ & $7.3 \times 10^{-2}$ & $1.0 \times 10^{-3}$ & $3.0 \times 10^{-2}$ \\
\hline 7 & Cadmium (Cd) & $1.0 \times 10^{-3}$ & $9.0 \times 10^{-3}$ & $2.0 \times 10^{-4}$ & $1.7 \times 10^{-1}$ & $1.0 \times 10^{-2}$ & $2.0 \times 10^{-4}$ & $1.9 \times 10^{-1}$ \\
\hline 8 & Cobalt $(\mathrm{Co})$ & $6.0 \times 10^{-2}$ & $3.30 \times 10^{-2}$ & $1.0 \times 10^{-3}$ & $1.0 \times 10^{-2}$ & $3.7 \times 10^{-2}$ & $7.0 \times 10^{-4}$ & $1.0 \times 10^{-2}$ \\
\hline 9 & Strantium (Sr) & $6.0 \times 10^{-1}$ & $7.47 \times 10^{-1}$ & $1.40 \times 10^{-2}$ & $2.0 \times 10^{-2}$ & $8.2 \times 10^{-1}$ & $1.5 \times 10^{-2}$ & $2.0 \times 10^{-2}$ \\
\hline 10 & Barium (Ba) & $7.0 \times 10^{-2}$ & $1.82 \times 10^{-1}$ & $4.0 \times 10^{-3}$ & $4.0 \times 10^{-2}$ & $1.3 \times 10^{-1}$ & $2.6 \times 10^{-3}$ & $3.0 \times 10^{-2}$ \\
\hline 11 & Chromium (Cr) & 1.500 & $2.0 \times 10^{-2}$ & $4.0 \times 10^{-4}$ & $2.4 \times 10^{-4}$ & $2.5 \times 10^{-2}$ & $5.0 \times 10^{-4}$ & $3.0 \times 10^{-4}$ \\
\hline 12 & Cesium (Cs) & $5.0 \times 10^{-4}$ & $1.0 \times 10^{-3}$ & $2.0 \times 10^{-5}$ & $2.6 \times 10^{-3}$ & $3.0 \times 10^{-4}$ & $1.0 \times 10^{-5}$ & $5.7 \times 10^{-3}$ \\
\hline 13 & Arsenic (As) & $3.0 \times 10^{-4}$ & $1.0 \times 10^{-2}$ & $2.0 \times 10^{-4}$ & $3.8 \times 10^{-1}$ & $1.2 \times 10^{-2}$ & $2.0 \times 10^{-4}$ & $1.7 \times 10^{-1}$ \\
\hline
\end{tabular}

${ }^{a} \mathrm{RfD}$ in milligrams per kilogram of body weight per day

${ }^{\mathrm{b}}$ Intake in milligrams per day

${ }^{\mathrm{c}} \mathrm{ADD}$ in milligrams per kilogram body weight per day 
Acknowledgements The authors are thankful to the Bhabha Atomic Research Centre (BARC) for the financial support (Grant No. 2009/36/74-BRNS/2516 Dated 16/12/2009). The authors would like to thank the Chairman and all members of BRNS-NRFC Committee for their useful suggestions. Authors are thankful to the officials and scientific staff of NFC, Hyderabad, for their help and cooperation. Cooperation received from other colleagues is fully acknowledged.

Open Access This article is distributed under the terms of the Creative Commons Attribution 4.0 International License (http://creativeco mmons.org/licenses/by/4.0/), which permits unrestricted use, distribution, and reproduction in any medium, provided you give appropriate credit to the original author(s) and the source, provide a link to the Creative Commons license, and indicate if changes were made.

\section{References}

Abbasi SA, Abbasi N, Soni R (1998) Metals in the environment, 1st edn. Mital Publications, New Delhi, p 225

Abdel-Ghani NT, Elchaghaby GA (2007) Influence of operating conditions on the removal of $\mathrm{Cu}, \mathrm{Zn}, \mathrm{Cd}$ and $\mathrm{Pb}$ ions from wastewater by adsorption. Int J Environ Sci Technol 4:451-456

Ahmed MK, Baki MA, Islam MS, Kundu GK, Sarkar SK, Hossain MM (2015a) Human health risk assessment of heavy metals in tropical fish and shell fish collected from the river Buriganga, Bangladesh. Environ Sci Pollut Res. https://doi.org/10.1007/s1135 6-015-4813-z

Ahmed MK, Shaheen N, Islam MS, Al-Mamun MH, Islam S, Banu CP (2015b) Trace elements in two staple cereals (rice and wheat) and associated health risk implications in Bangladesh. Environ Monit Assess 187:326-336

CGWB (Central Ground Water Board) (2012-13) Ground water information Nalgonda district, Andhra Pradesh. http://www.cgwbg ovin/DistrictProfile/AP/Nalgonda.pdf. Accessed 17 May 2013

Dang HS, Jaiswal DD, Parameswaran M, Krishnamony S (1994) Physical anatomical, physiological and metabolic data for reference Asian man: a proposal. BARC (Bhabha Atomic Research Centre). Report no. BARC/1994/FE/043

Dang HS, Jaiswal DD, Parameswaran M, Deodhar KP, Krishnamony S (1996) Age dependent physical and anatomical Indian data for application in internal dosimetry. Radiat Prot Dosim 63:217-222

EPA-1 (2015) Sampling and analysis of waters, wastewaters, soils and wastes. http://www.epa.vic.gov.au/ /media/Publications/IWRG7 01.pdf. Accessed on 22 May 2015

Fry A (2005) Water facts and trends. World Business Council for Sustainable Development, Geneva, p 16

Gupta A, Rai DK, Pandey RS, Sharma B (2009) Analysis of some heavy metals in the Analysis of some heavy metals in the riverine water, sediments and fish from river Ganges at Allahabad. Environ Monit Assess 157:449-458

Hani H (1990) The analysis of inorganic and organic pollutants in soil with special regard to their bioavailability. Int J Environ Anal Chem 39:197-208
Helsel DR (2005) More than obvious: better methods for interpreting nondetect data. Environ Sci Technol 39(20):419A-423A. https:// doi.org/10.1021/es053368a

IS 10500 (2012) Drinking water specification (second revision). Bureau of Indian Standards, New Delhi

Islam MS, Ahmed MK, Habibullah-Al-Mamun M, Hoque MF (2015a) Preliminary assessment of heavy metal contamination in surface sediments from a river in Bangladesh. Environ Earth Sci 73:1837-1848

Islam MS, Ahmed MK, Raknuzzaman M, Habibullah-Al-Mamun M, Islam MK (2015b) Heavy metal pollution in surface water and sediment: a preliminary assessment of an urban river in a developing country. Ecol Indic 48:282-291

Jain SC, Mehta SC, Kumar B, Reddy AR, Nagaratnam A (1995) Formulation of the reference Indian adult: anatomical and physiological data. Health Phys 68:509-522

Johnson FM (1998) The genetic effects of environmental lead. Mutat Res 410:123-140

Khan S, Cao Q, Zheng YM, Huang YZ, Zhu YG (2008) Health risks of heavy metals in contaminated soils and food crops irrigated with wastewater in Beijing, China. Environ Pollut 152:686-692

Lasheen MR, El-Kholy G, Sharaby CM, Elsherif IY, El-Wakeel ST (2008) Assessment of selected metals in some water treatment plants and household tap water in Greater Cairo, Egypt. Manag Environ Qual 19:367-376

Masoud MA, Elewa AES, Ali AE, Mohamed EA (2005) Distribution of some metal concentrations in water and sediments of lake Edku, Egypt. Bull Chem Technol Maced 24(1):21-34

Miller JR, Hudson-Edwards KA, Lechler PJ, Preston D, Macklin MG (2004) Heavy metal contamination of water, soil and produce within riverine communities of the Río Pilcomayo basin, Bolivia. Sci Total Environ 320:189-209

Nouri J, Lorestani B, Yousefi N, Khorasani N, Hasani AH, Seif S, Cheraghi M (2011) Phytoremediation potential of native plants grown in the vicinity of Ahangaran lead-zinc mine (Hamedan, Iran). Environ Earth Sci 62:639-644

Tiwary TN, Mishra M (1985) A preliminary assignment of water quality index to major Indian rivers. Indian J Environ Prot 5:276-279

US-EPA (1993) Carcinogenicity assessment. IRIS (Integrated Risk Information System), 2003. US Environmental Protection Agency, Washington

WHO (1993) Guideline for drinking-water quality (vol. 1). Recommendations. World Health Organization, Geneva

Wilson B, Pyatt FB (2007) Heavy metal dispersion persistence, and bioaccumulation around an ancient copper mine situated in Anglesey, UK. Ecotoxicol Environ Saf 66:224-231

Publisher's Note Springer Nature remains neutral with regard to jurisdictional claims in published maps and institutional affiliations. 